\title{
Research on the Characteristics of the Curriculum System of Fashion Management Major in Foreign Universities
}

\author{
Chenggang $\mathrm{Li}^{1,2^{*}}$, Wenli $\mathrm{Li}^{3}$ \\ ${ }^{1}$ Network Economy, Electronic Business, Network Marketing, Management Innovation, Business School of BIFT, Beijing, China \\ ${ }^{2}$ Beijing Institute of Fashion Technology, Beijing, China \\ ${ }^{3}$ International Business, Beijing Institute of Fashion Technology, Beijing, China \\ Email: *ccid205@126.com
}

How to cite this paper: Li, C.G. and $\mathrm{Li}$ W.L. (2019) Research on the Characteristics of the Curriculum System of Fashion Management Major in Foreign Universities. Modern Economy, 10, 2201-2208. https://doi.org/10.4236/me.2019.1011138

Received: August 18, 2019

Accepted: November 8, 2019

Published: November 11, 2019

Copyright () 2019 by author(s) and Scientific Research Publishing Inc. This work is licensed under the Creative Commons Attribution International License (CC BY 4.0).

http://creativecommons.org/licenses/by/4.0/

\begin{abstract}
This paper takes the foreign fashion management professional course system as an example to improve the content system construction of domestic college fashion management courses through analysis and comparison. Firstly, it analyzes the professional orientation of fashion management in foreign fashion colleges. Secondly, it compares the curriculum system of Chinese and foreign fashion management, including the curriculum content and training methods. Finally, combined with the characteristics of colleges and universities, improving the curriculum system construction related to fashion management and innovating relevant fashion management curriculum promotes fashion management to be more scientific, systematic, and theoretical, and more in line with international standards.
\end{abstract}

\section{Keywords}

Chinese and Foreign Universities, Fashion Management Major, Curriculum System, Comparative Study

\section{Research Background and Issues}

The main contradiction in our society has been transformed into a contradiction between the people's growing needs for a better life and the development of inadequate imbalances. By promoting consumption upgrading and enhancing the people's sense of well-being and happiness, fashion continues to meet people's needs for a better life. At the same time, through the innovation and dissemination of new products and new modes, it has greatly eased China's imbalance and The issue of full development is a powerful driving force for realizing and pro- 
moting the high-quality development of the Chinese economy. In 2018, the "Opinions of the CPC Central Committee and the State Council on Improving the Mechanism of Promoting Consumption and Further Stimulating the Consumption Potential of Residents" were promulgated. The paper presents several opinions on building a more mature consumer segment and growing the growth point of consumption.

At present, many cities are developing fashion industry, and the demand for building fashion capital is increasing. Therefore, grasping development opportunities and exploring the development path of fashion industry have become the focus of attention of fashion industry [1]. Fashion industry is becoming the strategic attraction and core concern of building international cities and National Central cities. Its leading position in urban industry is increasing day by day [2], and it has become an important driving force of global economic development. After ten or more years, Beijing plans to build itself into a world-class fashion capital with cultural connotations, leading science and technology and leading fashion while building the basic framework of a modern international metropolis [3]. Shanghai attaches great importance to the development of creative industries and the construction of fashion capital. In the 13th Five-Year Plan outline, its development strategy is clearly defined as an important support for the city's continuous promotion of "innovation-driven development, economic transformation and upgrading". To this end, the Shanghai Economic and Credit Commission has set up a financial support fund project to promote the development of cultural and creative industries in Shanghai. It encourages enterprises and research institutions to set up creative and fashionable enterprises, tackle key issues and create a policy, economic, technological, social and competitive environment [4].

In the process of promoting the development of the fashion industry, colleges and universities play an important role in it. Universities combine resource advantages, talent advantages, and industry advantages to deliver a large amount of fresh blood to the fashion industry. However, due to the late rise of China's fashion field, there is still a certain gap between the theory and practice and mature foreign countries and regions. There are still many problems in the development of the promotion of the fashion industry and the acceleration of the internationalization of urban fashion industry.

China's fashion industry has gradually increased its share in the world market. This is closely related to the improvement of China's consumption level, the huge demographic dividend, and the open and inclusive development environment. The construction of fashion system has become a new trend leading fashion. A series of fashion cities with obvious cultural symbols, represented by Shanghai, have become an important force in leading fashion culture and fashion trend. Brand building, more attention, has become an important aspect of ensuring the development of history and extending the field of fashion. With the development of Internet technology, Internet media and Internet platform are 
playing a more and more important role in the development of fashion industry. In the development of fashion industry, some fundamental problems still perplex the development of fashion industry. For example, the problems of innovation, the cultural connotation that gives the product a sense of the times, and the precise grasp of consumer demand are still the main problems faced by the development of fashion industry.

Need to solve, the stone of other mountains, can attack jade, learn from the advanced and mature system of foreign countries, combined with the reality of China to innovate, is particularly important in the construction of college fashion management professional curriculum system. Therefore, this paper selects Southampton University, Manchester University, London Fashion Institute, Nottingham Trent University, Birmingham University, Sheffield University, Harriet University, Robert Gordon University, Huddersfield University, New York Fashion Institute, Sa Vanner University, Marangoni Fashion Design College, Beijing Fashion College, Donghua University, taking the fashion management content system of foreign universities as the analysis object, focusing on comparing the content system of Chinese and foreign college fashion management courses, and combining with Chinese characteristics, propose and improve the content system that conforms to Chinese college fashion management courses.

\section{The Cluster Analysis of the Fashion Management Professional Curriculum System}

The table below lists the content systems of fashion management courses at home and abroad.

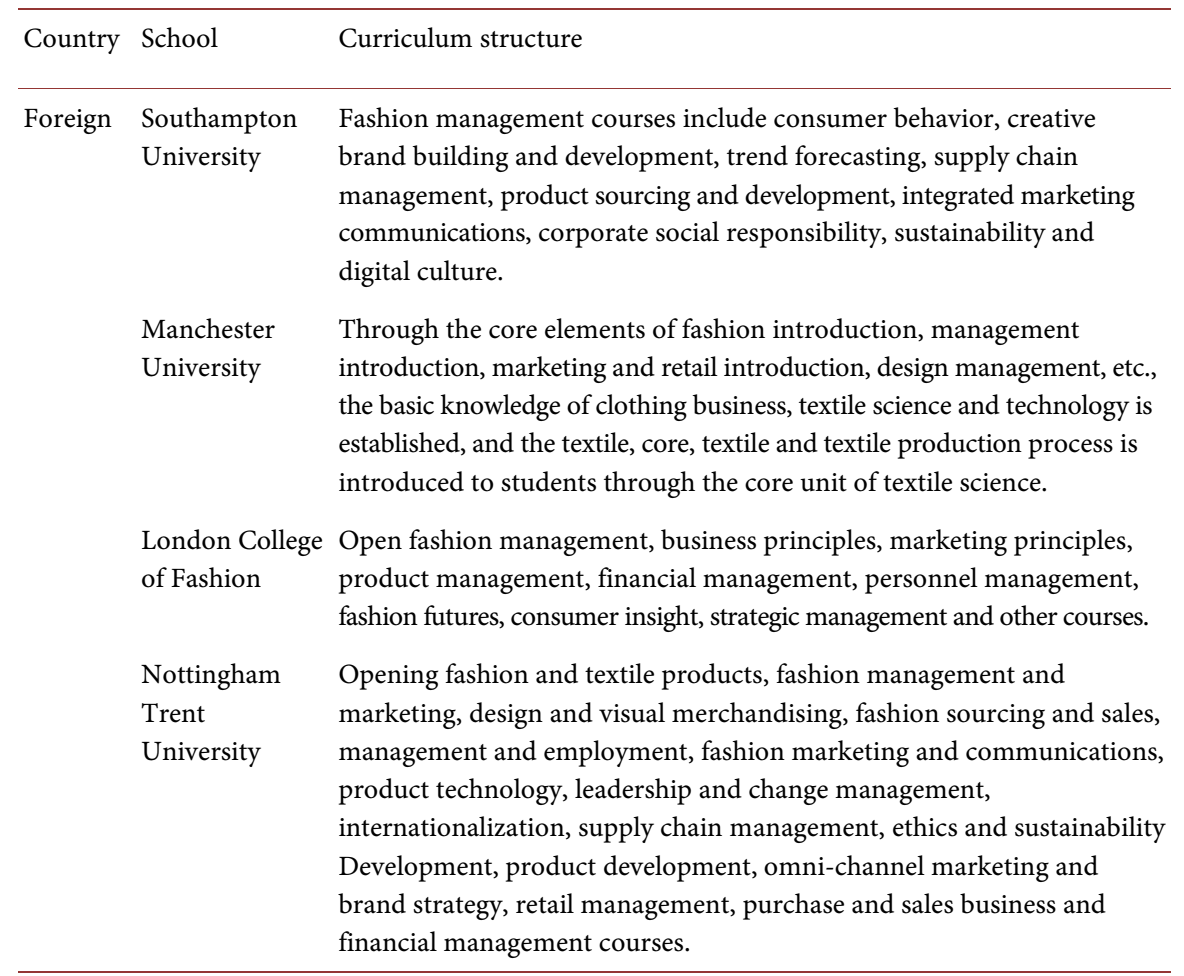




\section{Continued}

\begin{tabular}{|c|c|}
\hline $\begin{array}{l}\text { Birmingham } \\
\text { City University }\end{array}$ & $\begin{array}{l}\text { Open industry practice and background, global business management, } \\
\text { leadership development, research and professional skills, project } \\
\text { management, global fashion and branding. }\end{array}$ \\
\hline $\begin{array}{l}\text { d } \\
\text { sity }\end{array}$ & $\begin{array}{l}\text { Courses in Accounting and Financial Management, Introduction to } \\
\text { Creative Culture Industry, Critical Theory of Creative and Cultural } \\
\text { Industries, and Conceptual Culture Marketing. }\end{array}$ \\
\hline $\begin{array}{l}\text { att } \\
y\end{array}$ & $\begin{array}{l}\text { Courses on fashion management, design background, design projects, } \\
\text { design techniques and innovation, brand management, research } \\
\text { methods, raw material testing and exploration, and consumer } \\
\text { motivation. }\end{array}$ \\
\hline $\begin{array}{l}\text { Robert Gordon } \\
\text { University }\end{array}$ & $\begin{array}{l}\text { Open management and marketing subjects, fashion design concepts, } \\
\text { fashion construction, fashion retail and how fashion business } \\
\text { operations, advertising communications, public relations, consumer } \\
\text { behavior and logistics global, brand management, financial marketing, } \\
\text { ethics and event management theory, Subjects such as fashion buying } \\
\text { and global fashion strategies. }\end{array}$ \\
\hline $\begin{array}{l}\text { field } \\
\text { ty }\end{array}$ & $\begin{array}{l}\text { Open fashion background research, fashion professional development, } \\
\text { creative fashion industry, fashion practice, fashion creative research, } \\
\text { fashion futures, fashion identity, fashion creativity research and other } \\
\text { courses. }\end{array}$ \\
\hline $\begin{array}{l}\text { New York } \\
\text { Fashion } \\
\text { Institute }\end{array}$ & $\begin{array}{l}\text { Conducting fashion business management, fashion marketing, sales } \\
\text { management, fashion forecasting for apparel retailers, fashion inventory } \\
\text { management, sustainable fashion sales, retail fashion sales, fashion } \\
\text { planning and distribution, global marketing, computer-aided product } \\
\text { development, corporate social responsibility A series of lectures around } \\
\text { fashion management. }\end{array}$ \\
\hline $\begin{array}{l}\text { Savannah } \\
\text { University }\end{array}$ & $\begin{array}{l}\text { Introducing fashion accessories design, fashion design introduction, } \\
\text { digital presentation technology, fashion consumption, planning and } \\
\text { control, retail purchase simulation, and perfume marketing and } \\
\text { management courses. }\end{array}$ \\
\hline $\begin{array}{l}\text { Maranoni } \\
\text { Fashion Design } \\
\text { Institute }\end{array}$ & $\begin{array}{l}\text { Open marketing communication channels, digital marketing and new } \\
\text { media, business and management principles in fashion, fashion public } \\
\text { relations, promotion and advertising, fashion buying and selling, visual } \\
\text { display and merchandising. }\end{array}$ \\
\hline
\end{tabular}

In the process of analyzing the content system of fashion management majors in foreign universities, it is found that the relevant curriculum content around fashion management has formed a huge system. In the courses offered by many colleges, the names are not the same, but some courses Essentially the same. Therefore, it is necessary to combine courses from different universities to simplify the selection of evaluation indicators.

According to the existing course content system, the merged fashion management courses of colleges and universities are used as evaluation indicators. According to the actual characteristics of the evaluation indicators, this study divides 20 evaluation indicators into four different evaluation aspects, which are professional basic theoretical types (9 indicators), practical operation type (3 indicators), innovative creative type (4 indicators), ethics and sustainable development (4 indicators). 
First, professional basic theoretical courses. It is mainly a series of courses or courses that provide basic knowledge and basic theories to develop students' basic abilities and basic qualities. Including fashion marketing, fashion brand management, fashion management, fashion communication, logistics and supply chain management, design management, retail management, purchase and sales business and financial management, consumer behavior.

Second, practice operational courses. Practical operational courses are mainly learning activities for the comprehensive application of knowledge. Guide practical courses that focus on the combined use of knowledge and skills. It mainly includes product development and design, window display and merchandise display, and fashion practice. Among them, the fashion practice has different schools, and it combines the fields and characteristics of their respective schools to carry out practical curriculum learning activities.

Third, innovative creative courses. This type of course mainly cultivates students' sense of innovation, innovation and innovation. Innovation is the foundation of fashion, and the curriculum system strengthens the setting of this part of the curriculum. Including fashion creative research, creative fashion industry, digital presentation technology, perfume marketing and management.

Fourth, ethics and sustainable development courses. Courses that are of a quality education type include corporate social responsibility, sustainable development, business principles, ethics and social development.

\section{The Study on the Characteristics of the Curriculum System of Fashion Management Majors in Foreign Universities}

1) Relying on the advantages of the school, flexibly setting up courses

Depending on the background and advantages of each university, each university flexibly sets up corresponding courses. Relying on the advantages of textile industry, University of Manchester has set up the core unit of textile science to introduce the production process of fiber materials, fabrics and textiles to students. Nottingham Trent University focuses on driving, marketing, business and management courses. The New York Fashion Institute offers a series of courses related to the clothing supply chain, etc.

2) Marketing courses are valued as basic courses

Compared with the curriculum setting of various universities, marketing courses are the most versatile, including marketing and retail introduction, marketing, marketing principles, global marketing, and basically all colleges and universities are setting up similar courses. This has a certain relationship with the fashion consumption characteristics. On the one hand, history is mainly concentrated in the field of consumer consumption. He is more satisfied with the needs of personal life, and this individual consumer is widely distributed, with a large number of people, and the difference is large. The consumption characteristics of individuals such as transgender and part of irrational emotionalization, such consumption behavior characteristics, require marketers to 
conduct systematic research. On the other hand, the fashion field can meet the material and spiritual needs, whether it is conspicuous. Luxury goods, or clothing, food and shelter in life, he can meet people's basic material needs, fashion products can also meet people's spiritual pleasure, because of his popularity and popularity and spirituality, so the characteristics of marketization are special. obvious. Marketing courses, focusing on the change of consumer demand and how enterprises respond to and meet the change of consumer demand, play an important role in the realization of the value of fashion products and the healthy development of fashion field.

3) Indispensable for financial courses

As a management course, foreign fashion management courses generally include financial management courses such as financial management, accounting and financial management, and financial marketing. Financial management courses are offered at London Fashion Institute, Nottingham Trent University, Sheffield University, and Robert Gordon University. Financial courses, like marketing courses, exist as professional foundation courses, as basic qualities and abilities. As a management major, fashion management requires the college to master the basic theory of management and have the general ability of management. Financial management courses are courses that enable students to have such basic quality and ability.

4) The practical curriculum is in an important position

From the data analysis, the practical requirements of foreign fashion management courses are very high. It not only runs through professional basic courses, but also has a practical and practical course in the innovative and entrepreneurial curriculum ethics and sustainable development curriculum. From their course introduction, it can be seen that the case social survey and practice report The writing, as well as the integration of relevant knowledge, is a relatively normalized model in their curriculum.

5) Innovative courses are essential

Regarding the setting of such courses, foreign universities have different ways of setting up, some are courses such as creative fashion industry. Obviously, this is to let the students fully understand the creative characteristics and essence of the industry, and some are digital demonstration technology, from technology. From the perspective of strengthening the propaganda and performance of their own characteristics, some are fashion creative research, focusing on the creative and design part of fashion. In either form, it is developing students' self-innovation awareness and ability. Such courses are very important in market management.

\section{Improve the Relevant Recommendations of the Fashion Curriculum Content System}

1) Defining the positioning of fashion management courses

Accurate positioning of fashion management is the basis of its curriculum. Universities can refer to the professional settings of foreign universities, establish 
fashion management as a professional or direction or group of students that can be independent, and clearly define the position of fashion management in school, constantly highlighting the status of fashion management in the profession. Through a series of integrations, we will achieve the sharing of advantageous resources and jointly improve and develop the fashion management system.

2) Enriching the content system of fashion management

On the one hand, the curriculum content of domestic universities is expanded with reference to the setting of foreign course content systems. The scope of fashion management is relatively wide. It not only includes the management of personal fashion items for decorative items such as jewellery and the fashion management of household items in the environment, but also the decoration of related things and situations in human survival and development. The landscaping of the environment is fashionable. Therefore, we must not only expand the curriculum content of fashion management in clothing accessories, but also combine the characteristics of other professions to explore the attributes of fashion management. At present, we can learn about the sustainable development and ethical aspects of fashion in foreign universities which will be incorporated into the fashion management system.

On the other hand, China has a long history of traditional Chinese classic culture. When studying the curriculum of foreign schools, we can consider incorporating our culture into the fashion management system. This is not only the inheritance of Chinese traditional culture, but also the development of Chinese culture. For example, Beijing Institute of Fashion has established the National Costume Museum, a cultural research institution that integrates collection, display, scientific research and teaching. It aims to serve the society, provide specialized resources for teaching and scientific research, and become a gene pool of national costume culture. The National Costume Museum conveys the richness and weight of Chinese culture to the world and has become a good platform for Chinese clothing culture exchange and research. It plays an important role in inheriting, innovating and promoting Chinese traditional culture. Therefore, in the process of developing and perfecting the fashion management curriculum system, it is necessary to develop fashion management courses with Chinese characteristics; in the process of integration with internationalization, respect other countries' customs and habits and develop relevant courses.

3) Pay attention to development and improvement in practice

In the process of building a fashion management system, both domestic and international focus on practical development. In addition to the curriculum theory study, universities at home and abroad are combined with the fashion industry to arrange internship time, so that students can go deep into the fashion industry to learn. Learn to provide internships for fashion companies such as purchasing and sales, marketing and public relations, e-commerce and supply chain management, global sourcing, product development, apparel and fabric technology, and schools to encourage students to create their own brands. It is 
necessary to use internship as an extension of theoretical study, and to deeply understand and appreciate the context of the entire fashion industry in practice. Fashion companies should support and encourage student internships and provide internship opportunities to students. Through the cooperation between the school and the enterprise, the teacher can be employed as a position in the enterprise. During the internship process, the teacher guides the student to work, allows the student to quickly adapt to the company environment and the work content, and jointly cultivates high-level fashion management talents with professional qualities for the students. Pioneering career, attracting more talents for the fashion industry, and constantly enriching the fashion connotation.

\section{Conclusion}

This paper initially discusses the characteristics of the curriculum system of Fashion Management Major in foreign universities. It focuses on the structure and content of the curriculum of Fashion Management Major in foreign universities. It is hoped that it will provide some inspiration and reference for the curriculum of market management major in China. From the content of the article, the research and description of the current fashion Management Specialty in China are slightly inadequate. There is no sharp contrast between the two. I hope for further supplement and improve in the future research.

\section{Acknowledgements}

Fund Project: "Special fund for the construction of high-level teachers in Beijing Institute of Fashion Technology"-Beifu Scholars Program, project number: BIFTXZ201803.

The "2017 Light of Textiles" China Textile Industry Federation Higher Education Teaching Reform-innovation and entrepreneurship education into professional personnel training reform and practice of one of the results.

\section{Conflicts of Interest}

The authors declare no conflicts of interest regarding the publication of this paper.

\section{References}

[1] Wu, G.Y., Si, Y.H. and Wang, A.B. (2010) Basic Thinking on the Establishment of Shanghai International Fashion Center. Shanghai Textile Science and Technology, 38, 1-4.

[2] Yan, H.F. (2008) Developing Fashion Industry to Build Fashion Capital. Qingdao Daily, 2018-08-01 (008).

[3] Wang, W. (2010) Enlightenment of the Successful Experience of Paris as a World Fashion Center for Building Beijing into a Fashion Capital. Beijing Institute of Clothing Technology, 2010, 35-42.

[4] Yuan, L.J. and Xie, F.J. (2017) Countermeasures for Shanghai to Build an International Fashion Capital. Scientific Development, 12, 42-47. 